\title{
GARAMVÖLGYI LÁSZLÓ
}

\section{A bünmegelőzés távlatai}

Tény, hogy a XXI. században erősen felértékelődik a bünmegelőzés, azonban a posztmodern társadalmak csak mostanság szembesülnek a globalizációs technológia dermesztő kriminális veszélyeivel. Pedig Nils Cristie még 1978ban felismerte, hogy a büntetőpolitika nem váltotta be a hozzá füzött reményeket, mert az állam tehetetlen a lumpenelemekkel: a deviáns, antiszociális, folytonos normasértőket már egyszerüen nem fenyegethetik azzal, hogy elveszik/elvesztik szabadságukat, munkájukat, családjukat, társadalmi kötődésüket, mert mindezeket régen elvesztették. Legfeljebb egy négyzetméternyi gyékényt vagy hullámpapírt kockáztatnak, tehát a retorzió kilátába helyezése hatástalan. A szigorodó szankciórendszerek, az erőltetett kriminál- és büntetőpolitikai, illetve resztoratív megoldások alkalmatlanok a bünözés kezelésére, amit mostanra a kontinentális jogfelfogás kénytelen-kelletlen, de beismert. Az uralkodó álláspont szerint a bünözés ugyanolyan emberi tulajdonság, mint bármi más. Kétségtelenül deviancia, de egy tekintet alá esik az alkoholizmussal, a kábítószer-fogyasztással vagy a játékszenvedéllyel. Egyszerúen meg kellett adnunk magunkat a társadalmi anómiáknak.

Mindennek tetejébe elöttünk van az Ulrich Beck megfogalmazása szerinti kockázattársadalom, amolyan modernen túli világ, amiben a nemzeti intézményrendszerek globálissá válnak, a mindennapi élet pedig kiszabadul a hagyomány és a szokás szorításából. A régi társadalmak eltűnőfélben vannak, helyébe az új rizikófaktorokkal terhelt világ lép a gyakran kontroll nélküli szédületes technológiai fejlödés közepette. Nem véletlen, hogy Anthony Giddens egyenesen kitermelt kockázatról beszél, olyan helyzetről, amely a szereplők számára kilátástalan, bár ő a megoldást a társadalmi reflexivitásban látja. Szerinte az információs technológia világában lehetőség van a megfelelő reakciókra, de ehhez szüntelenül gondolkodnunk kell, és figyelnünk a minket körülvevő világ változásaira. Tény, hogy az életünk erőforrásválsággal terhelt, lassan elérjük kiaknázásuk végső határát, az éghajlatváltozással pedig a bioszféra hulladékbefogadó képességének határait feszegetjük. Nyakunkon még számtalan további nehézség: gazdasági-politikai-társadalmi válságok, háborús konfliktusok, éhezés-éhínség, természeti-, illetve klímakatasztrófák, terrorizmus, migráció és lehetne sorolni. Az is igaz, hogy a 
globális fenyegetettség ellenére az egyes társadalmak (nemzetállamok) esetében más-más kockázati tényezőkkel kell számolnunk, mert nyilvánvalóan eltérők azok a körülmények, amelyek befolyásolják a kedvezőtlen végkifejletet, függően attól, milyen a prevenciós erőtér. Célszerübb tehát veszélymegelőzésről beszélnünk - már amennyiben a bünmegelőzés hatékonyságát tartjuk szem előtt -, mert a veszély nem más, mint az a kriminogén tényező, amelyből kriminalitás lesz.

Feloldhatatlannak tünő ellentmondás, hogy miközben viharsebesen fejlödött a technika, az ember évezredek óta semmit sem változott. Amennyiben csak Krisztusig megyünk vissza, akkor azt lájuk, hogy a míves ókori drámák emberábrázolása ugyanolyan, mint ma, fikarcnyi különbség sincs, miközben a természeti és az épített környezet teljesen megváltozott, hogy a technológia fejlődéséről már ne is beszéljünk. Az ember nembeli lényegéhez tartozó tulajdonságok, személyiségjegyek, alapérzelmek, mint a harag, a bosszú, a gyülölet, nyereségvágy, szexualitás - hogy csak az élet elleni deliktumok leggyakoribb motívumait vegyük -, ugyanazok. A tudomány kézenfekvő felfogása, hogy az embert ideje feljavítani, így is hívják a doktrínát: feljavított ember vagy techno sapiens. Logikus tehát, hogy a viselhető technológiákat rég felváltották a beépített technológiák, a mesterséges intelligenciák nemcsak pórusainkig, hanem génjeikig hatolnak.

Jogos lehet Yuval Noah Harari kérdése: ,,Miért járt sikerrel Marx és Lenin ott, ahol Hung és Mahdi kudarcot vallott? Nem azért, mert a szocialista humanizmus filozófiailag kifinomultabb, mint a keresztény vagy a muszlim teológia, hanem azért, mert Marx és Lenin inkább koruk technológiai és gazdasági valóságát igyekeztek megérteni, nem ösi szövegeket és profetikus álmokat." ${ }^{\prime}$ Magam sem vagyok nagy híve a szellemi archeológiának, különösen nem a bünmegelőzés impozáns történetiségében. Kétségtelen, a prevenció már jelen van a sumér kultúrákban, de Seneca gondolatai, hogy tudniillik a bünesetek bekövetkezése után arra kell törekedni, hogy ugyanaz még egyszer ne ismétlödhessen meg, tőrőlmetszett profilaxis. Egyet kell értenünk Beccaria sokat idézett megállapításával is, miszerint a büncselekményeket jobb megelőzni, mint büntetni, csakhogy évszázadok óta alig változik valami. Pontosabban, ami változik, az a technológia - elfogadva persze előnyeit -, az árnyoldalait viszont meg kell világítani. Axiomatikus tétel, hogy az emberiség történetében még sohasem sikerült semmilyen technológiai fejlődést megakadályozni, így van ez a digitalizációval is. Ám ahhoz, hogy ez létrejöhessen, be

1 Yuval Noah Harari: Homo Deus. A holnap rövid története. Animus Kiadó, Budapest, 2018, 235. o. 
kellett lépnünk a negyedik ipari forradalom korszakába, amit a tudományok szinguláris fejlődése tett lehetővé. Noha a fejlődés távlatai és irányai eléggé homályosak, aggasztóbb, hogy az alkalmazási-felhasználási területek sem ismertek, $\mathrm{s}$ fajunknak van elég rossz tapasztalata arról, amikor egy technológia illetéktelen kezekbe került. A végkifejletet illetően is elég borúlátók a prognózisok, hiszen a mesterséges intelligencia és az emberi tudat különválhat. Óva intett bennünket a nemrégiben elhunyt Stephen Hawking attól, hogy a mesterséges intelligenciákat kontroll nélkül fejlesszük és alkalmazzuk. A már hivatkozott Harari sem felhőtlenül optimista: „Az emberiség egyre inkább elveszti hitét a liberalizmusban, amely az elmúlt évtizedekben uralta a globális politikát, éppen akkor, amikor az információs és a biotechnológia összeolvadása a legnagyobb kihivás elé állit bennünket, amellyel valaha dolgunk akadt. " Érdemes azt is hozzátenni, hogy az emberek nemcsak a valamibe (ideológia, vallás, politikai meggyőződés stb.) vetett hitüket veszítik el, hanem gazdaságitársadalmi-politikai hasznosságukat is, amit persze még nem éreznek. Tudniillik a technológia elöbb-utóbb felülkerekedik, sem az egyéni emberi, sem pedig a kollektív értékre nem lesz szükség, pontosan a transzhumanizmus miatt. A technológia persze egy ideig az ember szellemi és fizikai fejlesztésére törekszik (kiiktatja a betegségeket, fogyatékosságokat, öregedést), később aztán szükségtelen és nemkívánatos lesz minden emberi attitüd, így az intellektus vagy a kultúra is. Vélhetően ez a technológia egyik legveszélyesebb időben még messze lévő - távlata, ahhoz viszont, hogy ez ne következzen be, látnunk kell a megelózés kilátásait is.

\section{Technológiai áttörés}

Hozzáértők az 1996-os esztendőt tartják a számítástechnika első diadalának, ugyanis az IBM által kifejlesztett Deep Blue nevü gép sakkban legyőzte az aktuális világbajnokot, Garri Kaszparovot. Az éljenzők rögtön odáig mentek miután egy észjátékról van szó -, hogy a számítógép gondolkodik, holott csak arról volt szó, hogy a szerkezet a programozott stratégiákat (kombinációkat) gyorsabban tudta alkalmazni. (Természetesen ebben az esetben is visszafordíthatatlan volt a fejlődés, mostanra az élet minden területén megjelentek a számítógépes algoritmusok, egyebek között a technosapiens-technológiákban is.) Hermann Ottóval kapcsolatban szokás emlegetni, hogy ő volt az utolsó poli-

2 Yuval Noah Harari: 21 lecke a 21. századra. Animus Kiadó, Budapest, 2018, 16. o. 
hisztor, hiszen egyszerre volt zoológus, néprajzkutató, régész és politikus is, ami a XIX. században még elment. A következő évszázad viszont - az újabb és újabb tudományágak megjelenése miatt - a szakosodásról szólt, mindenki igyekezett elmélyülni a saját szakmájában, tudományterületén, hiszen képtelenség mindenhez érteni. Mindezt kiválóan tükrözte a kezdeti robotizáció; eleinte csak egy-egy gépet állítottak munkába, majd hamarosan elterjedt a szalagrendszer, miáltal már komplett munkafolyamatokat tudtak kiváltani. Viszont az is igaz, hogy a számítástechnika alkalmazása ott a leglátványosabb, ahol a gépek beállításával növelhető a profit, tehát lesznek olyan munkakörök, amelyek ellátásához egyáltalán nem kell ember. A trend ezért megfordult; a technológia mindenhez kezd érteni, az ember egyre haszontalanabb, miközben minden okosabb. Bejelentették, London utcáin öt éven belül az összes taxi önvezetö lesz, az okosvárosokban okosjármüvek fognak közlekedni az utakon, de a kötött pályákon is, és mindenütt. A kérdés persze az, hogy mi lesz a robotizáció miatt munkájukat elvesztő emberekkel, illetve mindez milyen hatással lesz a kriminalitásra. Optimista felfogások szerint a technológia nyújtotta jólét és gazda $(\mathrm{g})$ ság lehetővé teszi majd a munkanélküliek eltartását anélkül, hogy nekik bármit is tenniük kellene. Ennek (ilyetén) bekövetkezésére azért ne vegyünk mérget, ám ha még így lenne is, mit kezdenének magukkal az embertömegek? Félő persze, hogy számuk a metaverzumot gyarapítja, hiszen már most, a több száz, háromdimenziós (3D) virtuális világban két és fél millió ember él úgy, hogy ki sem mozdul otthonról. Az emberiség meghackelése azzal is járhat, hogy a technológia jobban fogja ismerni az embert, mint ő saját magát. Mindazonáltal ha ez bekövetkezik, az algoritmusok tökéletesebbek lesznek, kevesebbet hibáznak, ezért maguk az emberek fogják rájuk bízni a döntéseket. Sőt, talán a jövő idejű fogalmazás is fölösleges, mivel már ma is használunk olyan alkalmazásokat, applikációkat, amelyek megtervezik helyettünk, mondjuk, az útvonalat, bár még mi döntünk, hogy melyiket választjuk. Közel az idö, amikor a gép határoz ebben, mert megbízunk benne.

A kérdés csak az, hogy a technológiák birtokosai mennyire önzőek, egy szük elit privilégiuma lesz-e a tudás, vagy számolhatunk-e valamiféle méltányossággal. Ismert, hogy az egyén számára hasznos viselkedés, az önzés egyenlőtlenségekhez vezet, amelyet úgy egyébként - bizonyos mértékig - az emberek elfogadnak. Ennek zsinórmértéke a méltányosság, viszont a szélsőséges önzés rendszerint nagyfokú méltánytalansághoz vezet, $\mathrm{s}$ ezt a társadalom egyedei, a velük szültetett igazságérzetük miatt, kevésbé tolerálják. A futurisztikus elképzelések szerint a technológiák birtokosai és a technológiai nincstelenek között nőni fog a szakadék, a távolodásnak fizikai következmé- 
nyei lesznek. Legjobb példa erre az építészet, a tehetősebbek már most is olyan lakóparkokban élnek, amelyekben valóságos hadsereg gondoskodik a biztonságukról, de a Japánban felépített első piramisváros is kiválóan érzékelteti a lényeget: a technológiák birtokosai benn élnek, a másodrendủ állampolgárok pedig kiszorulnak. Odabent teljes biztonság és jogkövetés lesz, kint pedig anarchia, amint ezt az 1995-ben készült Dredd bíró címü filmben - azóta még nagyon sok alkotásban - láthatjuk. (S ha már filmek: a Star Warsban felmutatott technológia 95 százaléka már müködik!)

Teljesen nyilvánvaló, hogy amikor modern bünmegelőzésről beszélünk, akkor a legújabb kockázati faktorokat kell górcső alá venni, azt a fajta kriminalitást, amelyben nem a büncselekmények mennyisége és gyakorisága a mérvadó, hanem a létszervezésünket fenyegető technológiai barbarizmus. A ma oly népszerü szimulációs elméletek gondolatkísérletére érdemes odafigyelni; a hétköznapi problémáink annyira lekötnek bennünket, hogy képtelenek vagyunk felismerni, amikor a virtuális valóság kelepcébe csalja agyunkat kimondottan az átverés céljából. Nyugtalanító, hogy tudósok már-már poszthumán jövőképet vizionálnak, miközben bennünket a sárga csekkek befizetésének roppant terhei nyomasztanak. Ugyan a digitális mátrix jéghideg leheletét érezzük tarkónkon, de tamáskodunk Nick Bostrom szuperintelligencia-elméletén, mert hihetetlennek tünik, hogy az MI-k valaha is megdöntsék az ember egyeduralmát. Elvakultabbak szerint evolúciós zsákutcába jutottunk - egyedfejlődésünknek valóban nincs sok tartaléka -, és közeli egy zombiapokalipszis. Magam nem vagyok ennyire borúlátó, viszont azon érdemes elgondolkodni, hogy miért alakult ki - még tudományos közegekben is - az a végletes elmélkedés, amely szerint a bünmegelőzés önálló diszciplína vagy csak egyszerü szakmai zsargon. A bünmegelőzés ennél többet érdemel!

\section{Új világrend}

A volt amerikai külügyminiszter, Henry Kissinger pár éve megjelent könyvében $^{3}$ világosan vázolja jövőképünket, amelynek gyökereit az 1648-ban megkötött vesztfáliai békéig vezeti vissza. Kétségtelen, a harmincéves háborút lezáró egyezmény jelentősen átrajzolta Európa térképét, de legalább ilyen fontos - stílszerüen - fegyvertény, hogy megfogalmazta az új hatalmi politika alapelveit. Az eredendően modernnek ható diplomáciai deklarációk is ha-

3 Henry Kissinger: World Order. Pengium Press, 2014 
mar gellert kaptak, mint ahogy - legalábbis történeti távlatban - a győzteseknek kikiáltott franciák és svédek sem tudták tartóssá tenni a békét. Mégis, már ekkor körvonalazódik valamiféle transznacionális délibáb, nemzetek feletti omnipotens hatalmi konstrukció, amely mostanra egy világkormány létrehozását sürgeti. Mi több, ezen intézmény pártolói egyenesen úgy fogalmaznak, hogy a világban meglévő konfliktusok okozói pontosan azok a makacs nemzetállamok, amelyek nem akarják elfogadni az új csúcsszerv irányítását és elavult módon ragaszkodnak autonómiájukhoz, területükhöz, nyelvükhöz és kultúrájukhoz. Jól csengő érvelésük szerint erre az új világrendre épp a globális instabilitás elkerülésének érdekében van szükség, érthetetlen tehát mindenféle nemzetállami csökönyösség. Az elözményekhez tartozik, hogy a két éve, 101 éves korában elhunyt David Rockefeller, 1973-ban létrehozta a Trilaterális Bizottságot (Egyesült Államok, az akkori Nyugat-Európa és Japán), amelyből aztán a G7-es, majd további világfórumok jöttek létre. A cél világos volt; kézbe venni a világgazdaság irányítását és megteremteni a globális rendszer zökkenőmentes kibontakozásának feltételeit. A felhalmozott és rendelkezésre álló tőkeerő azt is lehetővé tette, hogy pénzügyi ellenőrzés alá vonják a tömegmédiákat, miáltal olyan közvélemény-formáló mechanizmus kezdett el müködni, amely teljes mértékben megfelelt céljaiknak. (Minderröl bővebben és szakszerübben Udo Ulfkotte tud beszélni. ${ }^{4}$ ) Látok azonban egy nagy veszélyt! Amikor a nemzetközi pénzhatalmi nagytőke, a nemzetközi korrupt politikusok és a nemzetközi szervezett bünözés összeborulása megtörténik, akkor olyan kriminális triász jön létre, amellyel szemben a nemzetállamok szinte tehetetlenek. Szkeptikus vagyok abban az értelemben is, hogy miképp lehet a gyanús körülmények között felhalmozott gigászi tőkét legálisnak titulált transznacionális vállalkozásokban tisztára mosni, bennfentes és nagy hatalmú világpolitikai döntéshozók, és a nemzetközi szervezett bünözés asszisztenciája nélkül... Mert a kriminalitást a legszélesebb értelemben érdemes vizsgálni, a korrupciótól a terrorizmusig, hiszen utóbbi sem más, mint hogy embereket gyilkolnak, méghozzá intézményesített módon, egy hamis ideológia - és nem teológia! - alapján. Ahhoz sem férhet kétség, hogy a technológia legfőbb birtokosai a már vázolt kriminális triász potentátjai közül kerülnek ki, és „beiktatásuk” már eddig is változatos koreográfiával történt. Az internetes agymosás - egyébiránt a hibrid katonai hadviselés egyik zászlóshajója - implicit módja is feledhető, hiszen a doktrína immár eléggé megdolgozta a gyanútlan befogadót.

4 Udo Ulfkotte: Megvásárolt újságírók. Patmos Records Kiadó, Budapest, 2014 


\section{Tételes jogi aspektusok}

A kontinentális jogalkotásban nem látszik megtorpanni az a több évtizedes (büntető)jogi gyakorlat, amely - az életviszonyok változásaira reagálván - a társadalomra veszélyes cselekményeket és deviáns magatartásokat írott paszszusokban szankcionálja. A jogfelfogás fixa ideája, hogy az állam büntetőhatalma korlátlanul érvényesüljön, ráadásul a büntetés megtorlási funkciójának markáns érvényesítése mellett. Meghaladott ez a felfogás, ám amíg a halálbüntetés érvényben volt, csak-csak volt valamiféle indoka, amiröl persze azt gondoltuk, hogy a rendszerváltozás után sutba vágjuk, hiszen eltöröltük a legsúlyosabb retorziót. Helyébe az életfogytig tartó szabadságvesztés lépett, amivel persze csak a megtorlás látszatát kerültük el, hiszen az elkövető életét nem vettük el. Ám ettől függetlenül felborult a generális és speciális prevenció, illetve a megtorlás intézményének egyensúlya, hiszen az életfogytig tartó szabadságvesztés aligha szolgálhat bármiféle bủnmegelőzési célt, mert fogalmilag kizárt. Így van ez még akkor is, ha húsz-negyven évente (uniós gyakorlatoktól függően) ildomos megvizsgálni az elítélt reszocializációs állapotát, hiszen ilyen intervallumban a tevékeny megbánás értelmezhetetlen tényezővé válik.

Hamvas Béla 1962-ben, a Patmoszban így ír: ,,Kierkegaard-nak Az idő bírálata címü tanulmánya kezembe került. Nincs társadalom, nincs állam, nincs költészet, nincs gondolkodás, nincs vallás, ami van, romlott és hazug zürzavar. Pontosan így van, gondoltam. De ennek valamikor el kellett kezdödnie. Elkezdtem keresni a sötét pontot. A proton pszeudoszt, vagyis az elsö hazugságot... Visszafelé haladtam a múlt század közepétöl a francia forradalomig, a felvilágosodásig, a racionalizmusig, a középkoron át a görögökig, a héberekig, az egyiptomiakig, a primitivekig. A válságot mindenütt megtaláltam, de minden válság mélyebbre mutatott. A sötét pont még elöbb van, még elöbb. A jellegzetes európai hibát követtem el, a sötét pontot magamon kívül kerestem, holott bennem volt..." Stílszerüen: olyan transzparens egzisztencia ez, amely a végletekig egyszerüsíti a bonyolult lelki és globális folyamatokat, miáltal teljes mértékben áttetszővé válik a naturális lét, ezért aztán valamikor - életünkben csak pár ilyen pillanat van - képesek vagyunk szembenézni a meztelen valósággal, nyomorult vagy pazar sorsunkkal, ám a végső kérdés mindenképpen az: mi dolgunk a világban, illetve - picit elvonatkoztatva Tamási Árontól - milyen jövő vár ránk? Nagy valószínűséggel nem a tételes jogban fogjuk megtalálni a választ, és még csak nem is a Neumann-galaxis fenntartás

5 Hamvas Béla: Patmosz I-II. Budapest, 1992, 77. o. 
nélküli elfogadásában. Helytelen az a szociálantropológiai vélekedés is, amely abból a felfedezésből született, hogy a társadalmi élet valamennyi - gazdasági, technikai, politikai, jogi, esztétikai, vallási - aspektusa egyetlen jelentéssel bíró rendszert alkot, mert hajlamos az egészt a részek irányába müködtetni azzal, hogy egyes elemeknek logikai elsőbbséget ad. Nos, évszázadok óta ebben a csapdában vergődik a jogpozitivizmus, amelyből - önmaga erejéből - bizonyosan képtelen kitörni. Mégpedig azért, mert a tömegtársadalmakra az a jellemzö, hogy nagyon sok ember él együtt, akiknek a viselkedését - elvileg a társadalmi orientáció érdekében és a jogkövetés elvárásával - igen sok szabály regulázza. Az inkább kulturális antropológiai vélekedés szerint, minél több a jogszabály (oltalom, tiltás, szankció), abból - a nagy számok törvénye alapján - az individuum egyre többet fog megsérteni. Ha ez bekövetkezik, akkor közbizonytalanság keletkezik, ráadásul ebben az esetben még a jog is szuboptimálissá válik. Evidens megoldásnak tünhet, hogy a szellemi tudományok is mind jobban a természetjog irányába mozdulnak, ennek egyik legmarkánsabb jele a kritikai kriminológia, amelynek társadalmi-tudományos beágyazottsága még mindig csekély. Nagy valószínüséggel azért, mert bírálatának tárgya olyan társadalmi (hatalmi) érdekeket sért, amely a közösségeken basáskodó élősködők plazmolízisszerü leváltását sürgeti.

Jól tudom persze, hogy a kulturális antropológia hidegen hagyja a rideg tételes jogot, ami - lássuk be - nem lát az orránál tovább. Már csak azért sem, mert eltekint fajunk több évezredes szelekciós és akklimatizációs folyamataitól (az egyedek és civilizációk e genetikailag kódolt túlélési képességeitől), miközben a tektonikus globalizációs rizikófaktorokat sem érzi. A veszély épp abban van, hogy a szikkadt, élethelyzetünktől és létszervezésünktől gyakran elrugaszkodott normák a kiúttalanság és kilátástalanság pszichés béklyójába kötik az egyén cselekvési apparátusát, redukálják szubkultúrájának pozitív tapasztalatait (szokás, hagyomány, erkölcs, vallás, rituális szabályok), így viszszahúzzák a beletörődés és a passzivitás posványába. Holott a bünmegelőzés legnagyobb hajtóereje éppen a közösségek cselekvő, attraktív és szolidáris együttmüködésén alapul, kihangsúlyozva közösségteremtő és -megtartó kohéziós erejét. Nagy hiba ez, mert szembemegy a bünmegelőzésnek azzal az őszinte üzenetével, hogy az egyénnek nem jobb sorsot (egzisztenciát, karriert, sikert) ígér, s élete a jövőben sem lesz mesés és pazar (ezt senki nem állítja!), „csak” biztonságosabb, következésképpen áldozattá válása elkerülhető. Érdemes leszögezni: a konfidenciaintervallum szerint azok a nemzetállamok lesznek képesek leginkább és leghatásosabban ellenállni a globalizációs technológiákban rejlő veszélyeknek, amelyek prevenciós mozgósítási és megbirkózási 
képessége (rezilienciája) a legnagyobb. Két forrása is van ennek: a tanult attitűdök alapján fejlődhet a közösségek és az egyének prevenciós reakcióképessége, miközben evolúciós tapasztalatainkra hagyatkozva, fajunk képes lehet értelmes válaszokat adni drasztikus környezeti-társadalmi változásokra. Vitathatatlanul az emberi viselkedés magas fokon differenciált képességeire lesz szükség; legelőször a genetikailag kódolt erőszakot fogja számüzni - a szelekciós hivatkozások megszünésével - és a faj megtartása érdekében felértékelődik a kooperáció. Olyan orientációs reakciókra van tehát szükség (ha úgy tetszik, taxanómiákra), amely hitünkben, civilizációs kultúránkban, egyetemes morális értékrendünkben megerősít bennünket.

\section{Az eröszak}

Stephen Hawking másik intelme - a mesterséges intelligenciák esztelen fejlesztésének veszélye mellett - az emberi erőszak terjedésére vonatkozott. A zseni odáig ment, hogy a megoldást egy másik bolygón látta, ezért érthető módon nagy híve volt a Marsra telepítés projektjének. Elméletének fogyatékossága, hogy ha sikerülne is a vörös égitesten kialakítani az emberi élet feltételeit, oda elöször ugyanazok a földön élö agresszív egyedek kerülnének. Nehéz megbirkózni ösztönvilágunk karizmatikus jegyeivel, és most csak sugallatunk két alapelemére utalok, jelesül a zsákmányszerzésre és a fajfenntartásra. Az evolúció degenerációs behatásainak következtében a zsákmányszerzés ösztöneiből alakultak ki a vagyon elleni büncselekmények, a szexuális jellegü deliktumok pedig a fajfenntartás ösztöneire vezethetők vissza. A freudi meghatározástól picit elrugaszkodva, érdemes kiemelni az élet- és halálösztön problematikáját, mert amikor az utóbbi kifelé irányul, akkor már agressziós ösztönről beszélünk. Ismert, a latin agressio szóból eredő jelentés szerint minden olyan viselkedésformát értünk rajta, amelynek célja másnak testi sérelmet, fájdalmat vagy kárt okozni, mert az agresszív magatartás erre irányul. Etológiai értelemben persze ennek lehet tudományos magyarázata is, nem véletlen, hogy Hawking az erőszak fogalmával operált. Inkluzíve nyilvánvalóan ez is tartalmazza a primitív viselkedés legtöbb elemét, de mégis inkább a fajtársak feletti erőszakos hatalmat, uralmat, a mások feletti korlátlan rendelkezést, illetve - Konrad Lorenz megfogalmazása szerint - bírvágyat jelent. Az erőszakos deliktumoknak könyvtárnyi irodalmuk van - igaz, elenyésző számban foglalkoznak a bünmegelőzés és az erőszak kontextusával -, pedig releváns kérdéshez értünk. Amikor társadalmi egyenlőtlenségek- 
ről beszéltünk (odacitálva az önzést és a méltányosságot is), akkor zömmel a vagyoni, egzisztenciális, illetve a státus szerint különbségeket véltük meghatározónak. Dacára ezek feszélyező valóságának, mégis a társadalmi aszimmetria brutális mivoltát kell kiemelnünk, amely csak részben tükrözi a társadalmi egyenlőtlenségeket, hiszen az az erőszakban gyökeredzik. Sőt, annál veszélyesebb, minél jobban összekapcsolódik az elit ab ovo hierarchikus magaslataival és az erőszak alkalmazásával. Mindezt jól ismerjük A Keresztapa címü trilógiából. Nekünk a „hétköznapi” eröszakkal kell foglalkoznunk, amellyel az állampolgárok naponta találkoznak. Még dermesztőbb belegondolni, hogy a kriminalitás közvetlen veszélyének tudata/vélelme is szorongást, illetve félelmet válthat ki. Miközben jól tudjuk, hogy a félelem - pszichológiai értelemben - mindig konkrét, a szorongás meg rendszerint absztrakt, mégis elgondolkodtató ez a vélelmezett lelki nyomás, ami gyakran traumává transzformálódik. Van ennek egy kevésbé ismert magyarázata, mégpedig az, hogy - eltekintve a média manipulációitól, de nem figyelmen kívül hagyva - radikálisan átalakult a konfliktusok globális (regionális-lokális) viszonyrendszere. Azt kell tapasztalnunk, hogy a globális konfliktusok igen hamar megjelennek regionális szinteken is, majd hirtelen lokálisan szuperponálódnak. Még kritikusabb, amikor lokális problémák rögvest regionálissá válnak, majd globálissá eszkalálódnak. Erre tipikus példa az Iszlám Állam létrejötte! Sajnos a digitalizáció nemcsak a virtuális/valós teret szükíti, hanem a tudatunkat is. Következésképp a még távolinak tünő konfliktusokat is gyakran a börünkön érezzük függetlenül attól, hogy ennek van-e bármiféle realitása. Persze ezt sem lehet egy kézlegyintéssel elintézni, hiszen - maradva az ISIS példájánál - bizony bárhol megjelenhet a terrorizmus, különösen annak függvényében, hogy lassan kezdik teljesen felszámolni ezt a csinált államot. Mindazonáltal a kozmopolita kriminológiának - figyelemmel az elözőekre - inkább lokálisnak, mintsem totálisnak (globálisnak) kellene lennie, mert az általános veszély megfogalmazásával (,nagy bünözés várható mindenütt, mert szétszélednek a terroristák") nem több egy meteorológiai elörejelzésnél. Épp ezért vagy ennek ellenére a bünmegelőzésnek nemcsak novellisztikus társadalmi funkciója, hanem küldetése is van.

\section{Változik a PIN-kód}

Érdemes egy tételmondatot előrebocsátani: a modern kori profilaxis - antropológiai értelemben mindenképp - totális, mert a társadalomban olyan rend- 
szert lát, amelynek minden aspektusa, emberi reakciója (rezilienciája) és attitűdje szervesen kapcsolódik egymáshoz, túllépve a szellemi archeológia ortologikus ragaszkodásán, új kohéziós formákat, jelentéstartalmakat keres autentikussága érdekében. A posztmodern (ha tetszik: precíziós) bünmegelözésben - érthető módon - egyszerre vannak együtt a technikai és a szellemtudományok legújabb vívmányai. A „szabványszerü” reflexiós mechanizmusok új prevenciós erőtereket hoznak létre a radikálisan átprofilírozott kommunikációs rendszerekben. Mogorva és kedvetlen világunk nagy ellentmondása naturális életfelfogásunkban rejlik; miközben alábecsüljük a nyakunkon ülő félelem jelentőségét, a kiismerhetetlen és kiszámíthatatlan technológiai robbanás várható következményeit, aközben csillapíthatatlanul vágyunk a biztonságra. Vélelmezhetően ez a pszichés folyamat felerősödik, amelynek - ha tetszik, ha nem - katalizátora lesz a sokat emlegetett civilizációk harcának víziója. Vannak már ennek jelei, úgy hívják, hogy kényszerneurózis, olyan viselkedési defekt, amely normális körülmények között amúgy nem jönne létre, de ez - félő! - kiválthatja a tradicionális normakövető reakciókkal ellentétes tüneteket is.

Sok tekintetben túlhaladott a Maslow-piramis emberiszükséglet-ábrázolása, ám annyiban mégis helytálló, hogy a biztonság atavisztikus igénye változatlan. Mi több, egyenesen arányos a társadalmi konfliktusok, anómiák, krízis- és stresszhelyzetek, valamint a félelem és a szorongás, illetve a fantáziadús lélekrombolás növekedésével. A minőségi társadalomszervezésben az emocionális viszonyulás, a szolidaritás és a kooperáció azonos vektorú, ami egyébként elöfeltétele az áthagyományozott kulturális tudásnak. A természeti népek nemcsak azért voltak kitartók, mert harmóniában éltek a környezetükkel, hanem mert közösségeikben magas fokú tudástranszfer müködött, tapasztalatokkal és jó mintákkal modellezték a tanulható szerepeket. Következésképp a fényesre polírozott reflexív képességek ellenállási együtthatója mindenféle veszedelemmel szemben sikeres volt. Modern felfogásban ez azt jelenti, hogy a közösségek egyedei individuális fejlődésük szocializációjában készségszinten elsajátították a tradicionális kultúra meghatározó attitüdjeit egy végtelenül egyszerü interiorizációban. A következmény - ugyancsak mai szóhasználattal - az lett, hogy ez a védekezési (túlélési) mechanizmus olyan viselkedési komplexummá vált, amely az ember (ha tetszik, a fajhoz tartozás) objektív megközelítésén keresztül a társas viselkedés megelözési szimbólumrendszerében perfektuálódott.

Amikor Szent-Györgyi Albert 1970-ben úgy fogalmazott, hogy az emberiség története egy nagy bűnügyi történet, akkor - az előbb általam is vázolt emberi erőszakra is gondolt. Ma már tudjuk, fajunk jegyzett krónikájában ed- 
dig tizennégyezer-ötszáz háborúban három és fél milliárd ember vesztette életét! Némi túlzással: az erőszak a legveszélyesebb baktérium, illetve vírus. A már ugyancsak idézett Hamvas Béla szkeptikus kérdésfelvetése talán most a legaktuálisabb, hogy tudniillik kétezer éves fejlődésünket tekintve mostanra paradicsomi állapotoknak kellene uralkodniuk, és az édenben élhetnénk, de hát végletesen gellert kapott mindenféle társadalmi berendezkedés. Evidens tehát, hogy a korábbi (és persze a mai!) társadalmi-gazdasági-politikai tényezők meghatározzák a profilaxis mozgásterét, egyáltalán a prevenció kibontakozásának lehetőségét.

Az eddig taglaltak figyelembevételével így néz ki a bünmegelőzés aktuális PIN-kódja; 5432. Az 5-ös értelemszerüen a már tárgyalt jogi (büntetőjogi) eszközrendszer, az erőltetett tételes jogi szabályozás, a 4-es a releváns társadalmi gondok és melléfogások, aktuális élővilágunk, a 3-as a nemzetközi környezet, illetve ezek akut tényezői, beleértve a technológiák exportját is, és végül a 2-es az egyetemes, illetve a nemzetállami bünmegelőzési kultúra. Nos, a profilaxis nagy elönye, hogy képes bemutatni, köntörfalazás nélkül vázolni a kriminális valóságot, kerülve minden szemfényvesztést és álteóriákat. Ehhez még akkor is ragaszkodni érdemes, ha a végkifejlet lehangoló és siralmas. Söt, konzekvensnek kell abban is lenni, hogy fikarcnyit se engedjünk az eredményességet garantáló matériából, hiszen a bünmegelőzésnek egyszerre kell müködnie az egyén, a közösség és az ökoszisztéma szintjén. Érezzük, a jövő nem olyan, mint szokott lenni!

Könnyü belátni, hogy a formális társadalmi struktúrák inkább ciklikus, mintsem tranzitív jellegüek voltak, így a kriminalitás elleni küzdelem (rendpártiság) inkább kampányjellegü témaként szerepelt az égetően megoldandó társadalmi problémák között, semmilyen elsőséget nem élvezve, a többi - egyébként igencsak súlyos - neuralgikus populációs rendellenességek tekintetében. Változnia kell tehát a bünmegelőzés PIN-kódjának, mégpedig így: 2435!

\section{Megoldási kísérletek}

Ki kell nyilvánítani, hogy - látható módon - az önkényesen magasabbnak és aktívabbnak kikiáltott kultúra (világkormány) leértékeli az egyszerübbet és passzívabbat (ami egyébként nem mellesleg a közjót szolgálja), alantasabbnak is tartja. Csakhogy a nemzetállamok egyedi adottsága éppen az, hogy a változó környezet ellenére - képesek a kulturális értékek, a ritualizált etikai normák magas szintü korrekciós képességére, ami a bünmegelőzés legna- 
gyobb muníciója. A társadalmi becsek amortizálódásának ellenére - az erős nemzetállamok - eredményesen ellenállhatnak a globalizációs próbatételeknek. ,,Semmi sincs a véletlenre bizva - írja Claude Lévi-Strauss -, és az egész erkölcsi és társadalmi életet az a kettös elv itatja át, hogy minden dolognak meg kell legyen a maga helye, és hogy minden dolognak a helyén kell lennie. Ez azt is megmagyarázza, hogyan lehetséges, hogy nagyon alacsony technikai-gazdasági szinten álló társadalmak úgy érezhetik, jólétben és böségben élnek, és mindegyikük meg van gyözödve arról, hogy az egyetlen élet, amelyet élni érdemes az övék. Talán ilyen módon több boldogságot tartogatnak a tagjaik számára."

Mindazonáltal az állampolgárok a hatóságoktól várják a megoldást, az egyik ilyen kísérleti bünmegelőzési koncepció a prediktív rendészet vagy az előre látó rendőrség. Egyébként az Egyesült Államokban már tizenkilenc úgynevezett digitális rendőrség müködik, amely a modern technológia minden arzenálját a prevenció szolgálatába állította. (Közbevetőleg érdemes megjegyezni, hogy a kriminalitás elleni küzdelem ontogenezisében most lenne először lehetőség nem csak szemantikailag felülírni a hagyományos módszereket, és bebizonyítani, hogy a bünüldözés bünmegelőzéssé transzformálható. Épp a digitális elkövetési magatartások és módszerek kínálnak erre lehetőséget, pusztán a törvényes oldalt kellene képzettebbé tenni, mert hát lássuk be: etikus hackerek nincsenek. A digitalizáció veszélye abban is áll, hogy - maradva csak a világhálón elkövetett deliktumoknál - az internet egyszerre tárgya és eszköze a büncselekményeknek.) Számos tengerentúli és európai próbálkozásról tudunk, amelyekben a nyomozó hatóságok kísérletet tesznek a legkorszerübb technológia alkalmazására a büncselekmények megelózése érdekében. Még akkor is figyelemre méltó eredményeket érnek el, ha a módszer kimerül abban, hogy különféle (kültéri-beltéri) kamerarendszereket, térfigyelőegységeket kötnek össze naprakész rendőrségi adatbázisokkal, kapcsolnak egymáshoz dokumentáló és monitoringrendszereket. Leleményes kommunikációval azt sugallják, hogy viszonylagos biztonsággal megjósolható - a speciális algoritmusok alapján -, hogy hol és milyen büncselekményt fognak elkövetni. Szikinger István erröl így ír: „,2002 nyarán mutatták be Steven Spielberg Különvélemény (Minority Report) címü filmjét Amerikában. Néhány hónappal később már Magyarországon is meg lehetett nézni. A történet 2054ben játszódik, és egy különleges bünmegelözési rendöri osztagról szól, amelyik három látnok jelzése alapján már a büncselekmény elkövetése elött meg-

6 Claude Lévi-Strauss: Strukturális antropológia I-II. Budapest, 2001, 255. o. 
bünteti a leendö gyilkosokat. Nem vagyunk távol attól, hogy ez a fikció valósággá váljék." " A film és a koncepció egyértelmü előzménye a népszerü sci-fi író, Philip K. Dick Különvélemény címủ novellájából született, amelyet 1963ban (!) írt, és a gondolatrendőrséget vizionálja. Lényege, hogy már a büncselekmény elkövetése előtt, de még csak nem is az előkészületi, hanem a tervezési (gondolati) fázisban kiiktatják a leendő elkövetőt, ami azért, lássuk be nem csak jogilag -, eléggé abszurd. A lényeg viszont az, hogy mindenütt a világon igyekeznek a hatóságok, a legmodernebb technológia hadrendbe állításával megfelelni valamiféle társadalmi-politikai elvárásnak, ami akár még sikeres is lehet. Hozzunk ide még egy filmet, a 2016-ban készült Tökéletes fegyver címü amerikai alkotást, amely ezzel a narrációval kezdődik: „,Amerika 2049... A cél a bünözés teljes megszüntetése. Az állam a barátjuk, a nehéz idökben az állam vigyáz önre és családjára."

A másik megoldást egy Irk Ferenctől származó idézettel kezdem: ,, Búcsút kell mondanunk annak a hiú ábrándnak, hogy a globalizáció árnyoldalait, a rizikótársadalom kockázatait büntetöjogi eszközökkel -bármilyen mostanában nagy igyekezettel kimódolni hivatott csürés-csavarással - befolyásolni lehet. Ennek egyik oka a távoli veszélyek nagyságának és bekövetkezése valószinüségének, káros hatásainak bizonytalansága. A másik ok az, hogy az indokoltnak tartott beavatkozás rizikója vállalásának azonnali vagy közeli idöpontban nagy vagy a bizonyossággal határos valószinüséggel bekövetkezö elönyei, gazdasági haszna mutatkozik. ",

Nos, a hatóság bünmegelőzés-centrikus tevékenysége (nálunk alaptörvényben rögzített feladata is), a különböző civil tevékenységek mind-mind szolgálhatják a prevenciót. Ám magam a megoldást mégis egy olyan társadalmi berendezkedésben látom, ahol előbb klaszterszerủen (ha tetszik, társadalmi ágazatonként) kezd el müködni a bünmegelőzési rendszer. Majd a polgári egységbe tömörülés, az önkéntes, de a jól felfogott egyéni érdekek alapján szerveződő szövetkezés és társulás a közjó céljait nemzeti szinten legitimálja. Végső célként - e társadalmi eltökéltség és elkötelezettség bázisán - létrejöhet egy valódi profilaxisalapú társadalom. Hiszek a kulturális antropológiában, a bünmegelőzés omnipotens racionalitásában. Amikor dadog a lét, akkor jön el a tiszta beszéd ideje. Vallom, az emberiség mihamarabb viszszatalál a damaszkuszi útra...

7 Szikinger István: Elörelátó rendőrség. In: Finszter Géza - Köhalmi László - Végh Zsuzsanna (szerk.): Egy jobb világot hátrahagyni. Tanulmányok Korinek László professzor tiszteletére. Pécs, 2016, 558. o. 8 Irk Ferenc: Kétkedő kriminológia. A rizikótársadalom kriminálszociológiája. Bíbor Kiadó, Miskolc, 2012, 296. o. 